\title{
The Philosophy of Theory U: A Critical Examination
}

\author{
Peter W. Heller ${ }^{1}$
}

Published online: 27 April 2018

(C) The Author(s) 2018

\begin{abstract}
Over the last ten years, „Theory U”, written by C.O. Scharmer in 2007, has earned broad international recognition. However, critical reviews of its grounding in social sciences and philosophy have been rare. After a brief introduction to Theory $U$ this article examines its methodic approach in the context of its references to the universal history of Toynbee, and epistemological sources in the works of Nietzsche, Capra, Varela, Husserl, and Steiner. The investigation of Theory U's historical and philosophical grounding comes to the conclusion that it is evidently falling short of adequately capturing real world complexity and does not match widely accepted academic standards. Despite its evident deficiencies, Theory U deserves the merit of uniquely embracing non conventional schools of thought beyond the mainstream literature on leadership theories.
\end{abstract}

Keywords Theory·Leadership · Epistemology

\section{Introduction}

Since 2007, C. Otto Scharmer's “Theory U” (Scharmer 2007/2016 ${ }^{1}$; cited as TU) has been met with many appraisals by practitioners in the field of leadership education, organisational learning and management training. The book of the Senior Lecturer at MIT Sloan School of Management and Chair of the MIT IDEAS program for cross-sector innovation has been translated in 20 languages (MIT Sloan 2017), apparently it struck a cord at the dawn of the global financial crisis in 2007/2008. The second book on Theory U: "Leading from the Emerging Future" by O. Scharmer and K. Kaufer (Scharmer and Kaufer 2013; cited as LEF) further condensed and updated Theory $U$, it was an international success, too. In 2016, when the second edition of Theory U was released, Scharmer received the EU Leonardo Corporate Learning Award for Thought Leadership (EU Leonardo 2016). Over the last ten

${ }^{1}$ unless noted otherwise, citations from Theory U are taken from the first edition (2007)

Peter W. Heller

pwheller@ canopusfund.org

1 Canopus Foundation, Günterstalstr. 9a, D -, 79102 Freiburg, Germany 
years "action research" programmes based on Theory $U$ have been used by governments, corporations, banks and NGOs worldwide (Scharmer 2016, xli-xlviii).

Surprisingly, critical scrutiny of Theory $U$ by the scientific community has been rare. Gunnlaugson et al., editors of a first compilation of research articles on Theory U, remark:" ... to date very little has been written academically in response to the theory and its application in business contexts" (Gunnlaugson et al. 2013, xiii).

This article doesn't focus on those business contexts, but attempts to examine the foundation of Theory $U$ in the sphere of social sciences, and focuses on two key issues which, to my knowledge, are still widely unaddressed: the philosophical grounding of Theory $U$ and its narrative of the historic, economic and social evolution of society.

The following chapter gives a brief introduction to Theory $U$ with a focus on its historical and philosophical references. However, for readers who wish to delve deeper into Scharmer's thinking, that outline cannot adequately replace a thorough reading effort: $500+$ pages of "Theory U", and 250+ pages of "Leading from the Emerging Future".

In the second chapter, I explore the "challenge-response" model of historic, economic and social evolution embedded in Theory U, referring to Arnold Toynbee's theory of universal history.

In the third chapter, I examine the references of Scharmer to philosophical texts and thinkers "where we find ourselves grounded in the deeper philosophical assumptions about being (ontology) and knowing (epistemology)" (TU, 108), and assess the relevance and coherence of that assumed philosophical pedigree.

I conclude my critical examination of the philosophy of Theory $U$ by expressing a caveat where Theory $\mathrm{U}$, in all its narrative splendour and fresh grasp of non conventional thinking, gets overambitious and off-trail, compromising its theoretical validity and practical outreach. Finally, a brief practitioner's comment underlines the value of Theory $U$ in teaching heterodox concepts of management, leadership and entrepreneurship to students and managers alike.

\section{A Brief Summary of Theory U}

Theory U responds to a world in crisis. It confronts the reader with an "Age of Disruption" where the present social and economic infrastructure, based on a competitive market economy, is withering away. The landscape of pathologies outlined by Scharmer comprises first the ecological divide, the depletion and overuse of natural resources; second the social divide, manifest in the growing gap between rich and poor nations, economies and households; and third the spiritual divide evident in the increase of burnout, depression, and suicide.

Theory $U$ addresses those challenges of disruptive change from a personal, individualcentered approach. Readers are encouraged to suspend their judgments usually based on past patterns of social interaction, and open their minds and hearts for new forms of a more sustainable, equitable and healthy life. That transition occurs not just on the individual level, it creates related and concurrent change in the economic and social sphere. To illuminate the relevance of that transition for society at large, Theory $U$ applies a model of linear historic progress in four phases (chapter 3.) which gradually evolves from old patterns of authoritarian power governing the economy and civil society to "eco-system awareness" driven forms of cooperation. Scharmer refers to this process as the "journey of the U" (TU, 374). It is connected with 24 principles and practices, summarised in the following figure:

The "U" is a graphic expression of the journey's bent trajectory which first leads the traveller along the journey downwards, away from past convictions and prejudices, to a phase 
of "intentional silence" at the bottom of the U. The term "intentionality" plays an essential role in Theory U and marks the critical moment when the judgments and patterns of the "old self" are suspended: the individual has reached a point of introspection similar to a Cartesian or Husserlian reduction (chapter 4.4).

On the way upwards, the traveller finds a path from his solitary introspection back to intersubjective action and to society, a path now purged of the major social and personal pathologies, and finds himself capable of creating a better world in cooperation with others.

Scharmer captures the methodic approach of the U process by introducing the neologism "presencing": presencing blends "sensing" (feeling the future possibility) and "presence" (the state of being in the present moment). It signifies the capability to find and develop emerging solutions to overcome disruptions by "acting from the presence of what is wanting to emerge" (LEF, 19). As outlined in Fig. 1, Scharmer guides the reader in the U process through 24 principles and practices of "presencing", starting with a detachment or "letting go" and moving to a new intersubjective attachment or "letting come", realising a social awareness beyond predisposed convictions, reaching out to others and creating "circles" or core groups in an effort to "crystallize vision, intent" and "prototype strategic microcosms".

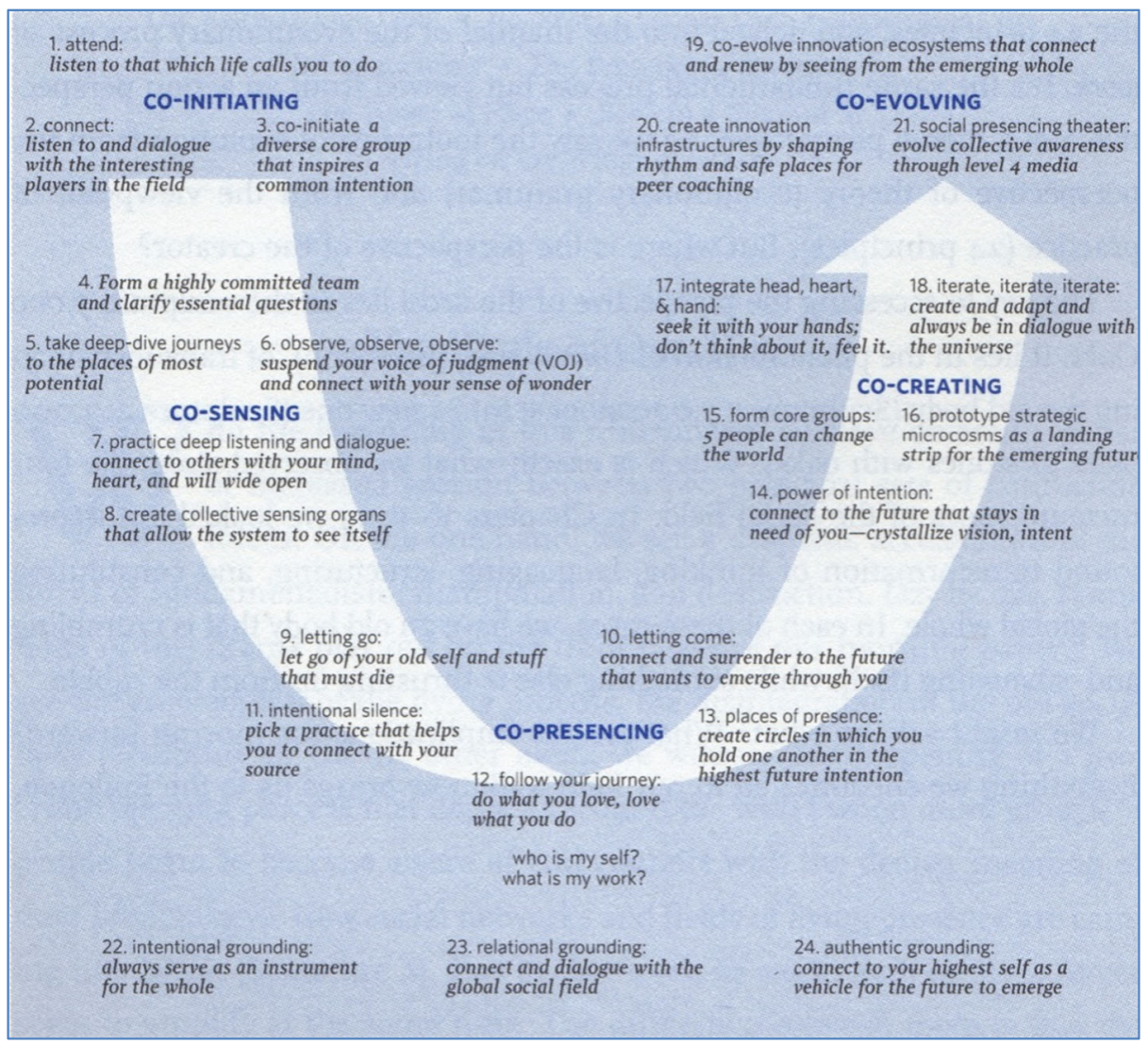

Fig. 1 Principles and Practices of the Journey of the U (TU, 441) (Reprinted with permission of the publisher. From "Theory U”, Copyright@ 2007 by C. Otto Scharmer, Berrett-Koehler Publishers, Inc., San Francisco, CA. All rights reserved. www.bkconnection.com) 
For the final phase on the upward part of the U Scharmer introduces the term "co-creation" which he owes to C.K. Prahalad and V. Ramaswamy. They define co-creation as "The joint creation of value by the company and the customer; allowing the customer to co-construct the service experience to suit their context". (Prahalad and Ramaswamy 2004, 8) Scharmer extends the meaning of co-creation to a more general process of prototyping new forms of economic and social action. Theory $\mathrm{U}$ introduces co-creation as the ultimate tool to overcome the existing economic, social, cultural and personal frictions and disruptions, thus to unleash a global transformation of the present world in crisis.

The brief overview may suffice to aquaint the reader with the basic methodical approach of Theory U. Now we explore its application to the evolution of the global society in historic, economic and social perspectives.

\section{The Evolution of Economic and Social History in Theory $U$}

Scharmer and Kaufer address economic and social history universally by applying a linear model of progress expressed in terms of information technology: "Society 1.0" signifies the "old" hierarchical government coordination mechanism, equivalent to old software technology (f.e. MS-DOS 1.0). Moving along the phases of "Society 2.0" (free market driven) and "Society 3.0" (stakeholder driven), the evolution finally reaches "Society 4.0" which stands for the stateof-the-art in societal coordination, in terminological analogy to the latest software products, or "Industry 4.0", the widely used term for the "Internet of Things", the full integration of digital communication between internet connected devices. The reasons for the application of that "techno-speak" 2 evoking the world of corporate marketing are nowhere substantiated; but it certainly adds a business or technology oriented "flavour" to the argumentation.

The ultimate phase "Society 4.0" is supposed to be coordinated by "presencing", unfolding an eco-system awareness which empowers a co-creative economy across the societal subsystems. Table 1 outlines Scharmer's approach to economic evolution:

The progress along the 1.0-4.0 trajectory is a rudimentary model of "universal history", introduced by Scharmer/Kaufer with an explicit reference to Arnold Toynbee's "challengeresponse" (Toynbee 1947, 569-570) model, elaborated in his monumental work "A Study of History" (Toynbee 1934). Universal history's synoptic view attempts to discover historic metatrends across the development of different civilisations on a global scale (in Toynbee's Study of History, 21 civilisations are thoroughly screened). Civilisations evolve in "response" to historic "challenges", their movers and shakers are "creative minorities" which devise specific solutions to the lack or scarcity of natural resources, pressure from neighbouring civilisations, or internal political gridlock. When these minorities loose their momentum and political creativity and degenerate into “dominant minorities", civilisations are doomed to decline and fall (Toynbee 1947, 578).

This is not the place to review the highly controversial debate about the epistemological background and merits of universal history as such, embedded in the tradition of Hegels philosophy of history, and later pursued by Marx, Spengler, Toynbee, and Curtius. ${ }^{3}$ Relevant for my argument later in chapter 3.2 is that Toynbee's "Study of History" has been frequently

\footnotetext{
${ }^{2}$ The ,techno speak"itself borrows the " $1.0-4.0$ " term from the phase model of industrial revolutions: 1.0 for the introduction of steampower and the factory system; 2.0 for the age of electricity and mass production; 3.0 for the digital revolution; 4.0 for the era of the internet of things and artificial intelligence. (Schwab 2015)

${ }^{3}$ For critical reflections on Toynbee's seminal work, see Montagu (1956)
} 
critisised to subordinate historical scholarship to his religious convictions and distorting historical facts until they seamlessly blend into his vision of "theodicy", of God revealing Himself in the course of the history of mankind (Coulborn 1956).

As Scharmer explains socioeconomic development in Theory $U$ as an application of Toynbee's challenge-response model (TU, 339), we shall take a closer look at the validity of that claim and the similarities and differences of both models.

\section{Evolutions of Nations and Corporations}

As outlined in Table 1, socioeconomic evolution in Theory $U$ follows, at least for its major part, a strictly linear model of challenge-response driven historic progress. Step by step, phase by phase the old authoritarian way of coercive governance gives way to the participation of more stakeholders, and ultimately develops a society based on an eco-system stewardship with lower violence and far less abuse of power. The introduction of the linear universal history model in Theory $U$ is not meant as a metaphor. Scharmer/Kaufer refer explicitly to historic events in different regions of the world which in their view mark a challenge-response driven evolution, an upward move towards eco-system stewardship: the end of the Thirty Years' War in Europe 1648, the Civil War in Russia 1917, the Chinese Civil War 1949, and the Great Depression in the US in the 1930s (LEF, 57-64).

However, history doesn't follow the progressive trajectories of software development, and Scharmer has to conclude that, somehow, all those regions are stuck somewhere in the first three phases. In order to save the argument, he highlights a few shining examples of progress:" The Arab revolution of $2011 \ldots$ is directed against the last strongholds of those cynical and corrupt 1.0 regimes" (LEF, 59). In early 2013, such an optimistic view of the "Arab spring" was understandable. But, looking back in 2018, that glimmer of hope has since been shredded to pieces after the Coup in Egypt, the emergence of ISES, and the wars in Lybia and Syria.

Another example is China: "China focuses ... on innovations to make progress on its path toward a harmonious society" (LEF, 60-61). Despite the intense propaganda of the Chinese government, political reality in the country looks entirely different in 2018, at least in light of the Western view of "harmonious societies" which are closely associated with a democratic system giving space to pluralistic values and opinions, a balance of power and the rule of law.

"The often harsh criticism in the Western media of Russia usually misses two points... it took the West an awfully long time to move from 1.0 ... to 2.0 ... Why not give Russia at least a few years to sort these things out?" (LEF, 64). Since 2013 Russia has indeed sorted some "things" out, but, after the annection of the Krim, its power game in Eastern Ukraine and the increasing pressure on civil society organisations, it has definitely not made much progress towards a governance model based on eco-system awareness.

In conclusion, the gap between political reality and the linear evolutionary progress assumed by Theory $\mathrm{U}$ is wide. Equally unsubstantiated is its claim to be an application of Toynbee's framework.

Toynbee interprets the development and decay of the 21 civilisations described in his work, their rise and fall as an essentially non-linear process: "The illusion of progress as something which proceeds in a straight line is an example of that tendency to over-simplification which the human mind displays in all its activities" (Toynbee 1947, 38). The model of historic evolution in Theory $U$ does exactly what Toynbee rejects as an over-simplification: step by step, on a linear trajectory, coercive power ("sticks") is replaced by remunerative power ("carrots"), which is replaced by stakeholder values which, finally, give way to eco-systemcentric awareness (LEF, 52). 
Scharmer is aware of that dilemma and and later suspends the idea of a strictly linear progress. Further along the U journey, in the field of economic evolution, economic logic and corporate development, we finally come across his important insight that "a linear process is somewhat misleading. Instead, we suggest seeing the evolution as a more circular process ... Western thought tends to conceive of history as a linear process, while the Eastern view is more cyclical. ... If we combine them, we end up with something like a spiral, or a U." (LEF, 76) Unfortunately, a spiral is not a U: in the final upward phase of co-creation no backspiralling would make sense in the context of Theory $U$, and plainly contradicts all the tables of historic, social and economic evolutions which constitute a core argument of Theory U.

The tentative bending of the linear trajectory into a $U$ - or a spiral - adds to the confusion in its historical perspective, and likewise continues the confusion in the section on the evolution of the corporate sector. Social-market economy corporations (phase 3.0; see Table 1) use "networks and negotiations" as a coordination mechanism, their purpose of business is supposed to be "eco-system domination" (not profit), their stakeholder relationships are "empathic but dominating". In my view that is a quite heroic assumption; Scharmer's examples are Nokia, Cisco, Toyota, Apple, Facebook, and Google (TU, 321; LEF, 226, Table 11). However, there is no comparative evidence given in the text that those corporations behave more empathic than GE or ABB, Microsoft or Oracle. The track record of the former companies is indeed mixed at best: shortly after 2009, when Theory U was written, Nokia's share price dropped by half as the corporation entirely lost its cutting-edge appeal in the mobile phone market, and was finally taken over by Microsoft; its top managements dramatic lack of understanding of the competitive dynamics of the mobile phone market, which led to a "company-wide inertia" (Vuori and Huy 2015) was the reason for that failure, not the corporation's more or less empathic behaviour. In 2009 Toyota caused a major scandal related to safety issues in its cars and had to pay a 1,2 bill. \$ fine to the US government. "Big Data" corporations like Google, Facebook or Apple don't show a convincing performance in the field of empathy, either (Clark 2017; Pfeffer 2015). The lack of loyalty of "Generation Y" employees to those IT corporations is seen as a common feature even in that privileged segment of the labour market (Bershidsky 2013).

Surprisingly, Scharmer/Kaufer see a manifestation of the forthcoming "presencing" corporation in the e-commerce sector: "The purpose of the 4.0 company is eco-system stewardship. The logic revolves around economies of presencing that is around sensing and actualizing emerging futures. Emerging examples of this category include ... the Chinese e-commerce giant Alibaba. The difference between 3.0 and 4.0 companies is intention: 3.0 companies are driven to dominate their eco-system, while 4.0 companies try to serve the well-being and shared ownership of all." (LEF, 227) As Alibaba is in Scharmer/Kaufer's view indeed a serious candidate for a 4.0 company, we have good reasons to be seriously concerned about that eco-system stewardship economy. The "Alibaba Fraud Report" comments in its introduction: "In fact ... the threat of fraud is inherently built into Alibaba.com's core business model, making fraud a constant and serious risk to buyers on the site." (Sun 2012, 2).

We have to conclude that in both perspectives, the historical and, regarding the corporate sector, the economic one, Scharmer/Kaufer's evolution model is purely fictional, ${ }^{5}$ and leads to

\footnotetext{
4 "The charge is that TOYOTA defrauded consumers in the fall of 2009 and early 2010 by issuing misleading statements about safety issues..." (US Department of Justice 2014)

${ }^{5}$ It calls to mind the purely fictional character of Adam Smith's "history" of money. Smith outlines a "barter economy" as the prototype of market exchange which historically has never existed in that form (Graeber 2011, 22-41).
} 


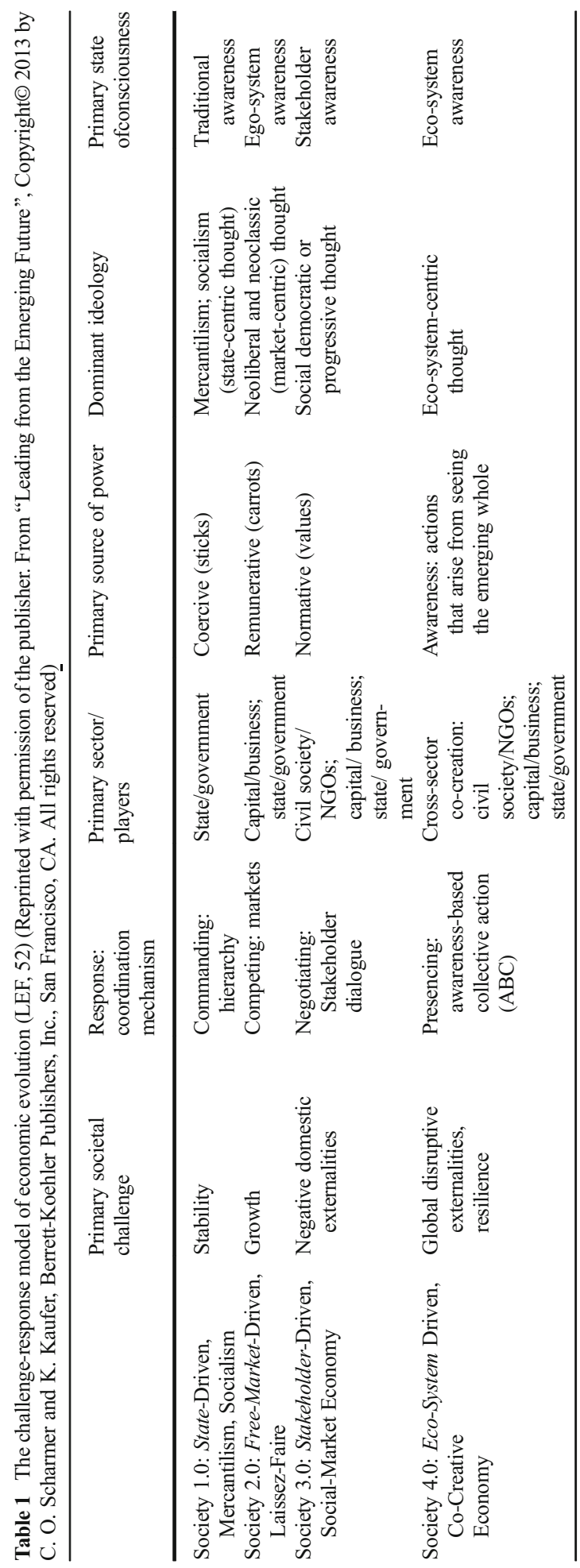


serious misperceptions about political reality, corporate accountability and value oriented performance.

\section{History and Prophesy}

For all their vast differences, the rudimentary linear approach of Scharmer/Kaufer faces a similar dilemma as Toynbee's empirically much more comprehensive non-linear model of history: both are using historical knowledge as a medium to convey their religious convictions.

Indeed, Scharmer's reference to Toynbee, despite their antagonistic views on the course of history, is not arbitrary. Both Toynbee and Scharmer are simultaneously scholars and believers, they have an important metaphysical trait in common: their work is united by an explicit and tangible eschatological mindset.

Tonybee's pessimistic view of the inevitable decline and decay of Western civilisation is, unlike Spengler's, balanced by the deep conviction that the Christian God will ultimately, and miraculously, lay the ground for a truly universal religion and thus save mankind: "His dream is the unity of mankind in the love of God" (Geyl 1955, 261). Critics of Toynbee such as Raymond Aron, Pieter Geyl and H.R. Trevor-Roper see his later turn as a transformation from a "historian" to a "prophet" (Aron 1961; Geyl 1955; Hale 2005; Montagu 1956).

Scharmer's journey to the world of eco-system stewardship, guided by the virtues of presencing, co-sensing and co-creating is based on a similar conviction: beyond the "Age of Disruption" lies the Promised Land. In Scharmer's narrative of the new world we encounter quite a number of biblical allusions or crypto-religious terms: f.e. the "three enemies", "the eye of the needle", the "voice of judgement/voice of fear", the "deep place / deep source of knowing". 6 The pathfinders to that promised land are (co-)creative "frontline" leaders in all segments of society: "This book (Theory $\mathrm{U}$ ) is written for leaders and change activists in corporations, governments, not-for-profit organization, and communities." (TU, 5).

In his universal history Toynbee calls those leaders members of the "creative minorities": “... the self-segregating minority devoted its energy to the task of finding some solution for a problem that confronted the whole society. And ... the creative minority returned in the fullness of time, when its work of creation was accomplished, to the society which it has temporarily abandoned, and set its impress upon the whole body social." (Toynbee 1947, 233-234) Toynbee's and Scharmer's visions of the agents of transformational change in society are close, and both are grounded in a pointedly elitist approach (more on that elitism in chapter 4). However, there is a fundamental difference. Toynbee's creative minorities which make civilisations rise and prosper, sooner or later turn into "dominant minorities" loosing momentum and transformational energy, leading their civilisations into decay and ultimately disintegration:" ... a failure of creative power in the creative minority, which henceforth becomes a merely 'dominant' minority; an answering withdrawal of allegiance and mimesis on the part of the majority; a consequent loss of social unity in the society as a whole." (Toynbee 1947, 578) That interpretation can hardly be applied to Scharmer's co-creative leaders who, as historically purely fictional characters stripped of any empirical evidence, cannot morph into "dominant" co-creative leaders, unless the entire line of argument collapses and eco-system stewardship is like any other phase in the endless cycles of

\footnotetext{
${ }^{6}$ I have to admit that Scharmer and Scharmer/Kaufer's inflationary use of the adjective "deep" gave me an increasingly annoying reading experience: in Theory U "deep(ly)/deep-" is used over 250 times, once every second page, a similar massive use is found in LEF. But such a quantity of "deepness" doesn't make our thinking any deeper.
} 
history. That final phase would loose its messianic quality which is inherently built into the role model of the flawless (and therefore timeless) Theory U type of leader.

In light of the historical evidence of the rise and fall of civilisations Toynbee has put his faith for salvation in the future resurrection of a universalised Christian religion. Instead, the new age envisioned by Scharmer has already reached that state of salvation, the logic of eco-system awareness based leadership doesn't leave any space for domination, decay and disintegration.

\section{The Philosophical Grounding of Theory U}

Chapter 6 of Theory $U$ is dedicated to its ontological and epistemological grounding. (TU, 105-110) It has 5 text pages out of 462 of the complete book, and doesn't give us more than a fragmented outline of the philosophical sources of Scharmer's work. ${ }^{7}$ Of the long list of thinkers whose names are briefly dropped I shall focus on the following which I see as preeminent sources of his philosophical pedigree: the work of Friedrich Nietzsche, the "Eastern" path paved by Fritjof Capra and Francisco Varela, Edmund Husserl's later writings, and Rudolf Steiner's anthroposophy.

\section{Nietzsche: Beauty and Truth, Last Men and Overmen}

The impact of Friedrich Nietzsche has apparently grown more prominent in the development of Theory U, with just two marginal remarks in the first book (2009), but two longer citations from his later work "Thus spake Zarathustra" in the latter one (2014) (LEF, 152-153, 213). Nietzsche's philosophy is the subject of one the most lively and controversial debates in twentieth century thinking, covering a vast range of positions from Georg Lukács' outright condemnation of Nietzsche as a central intellectual precursor of the nazist and fascist movements in the twentieth century (Lukács 1980), to Michel Foucault's defense of Nietzsche as the inventor of a counter-historical hermeneutic approach challenging conventional historical wisdom and ethics (Foucault 1977). A more balanced approach has been developed by Domenico Lusardo in his seminal work on Nietzsche (Losurdo 2009). He portrays the philosopher as an "aristocratic rebel", as a radical anti-political elitist (but not outright fascist) who strongly believed in the right to rule of "good and healthy" aristocratic leadership, even if "common" human beings would have to be sacrificed in the course of that rule. Nietzsche recognised the "raison d'être" of nations (or civilisations) primarily in generating "overmen" (Übermenschen) "beyond good and evil", free of any common constraints, who value beauty above truth, art above morality. They are "dancer(s) in the battle", as he expressed it in a famous metaphor of his late Dionysos-Dithyrambs poems.

We find an echo of that elitism both in Toynbee's "creative minorities" and in Scharmer's "4.0 change-makers". But unlike Toynbee, Scharmer's entirely apolitical view of power conflicts in society, methodically embedded in his leaders' journey of the U (see Ch. 4.3), finds its equal in Nietzsche's anti-political and anti-egalitarian furor. Therefore, Scharmer's double reference to "Thus spoke Zarathustra" makes sense: "It's what I like about Nietzsche. Most people today don't understand that beauty is primary to truth." (LEF, 221).

Ironically, essential ingredients of the 4.0 leadership model contain behavioural features which Nietzsche found most despising. The LOHAS (Lifestyles of Health and Sustainability)

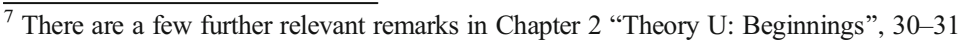


culture, cherished by Scharmer as an essential behavioural element of the 4.0 culture (LEF, 57), comprises mental empowerment such as meditation and "mindfulness" techniques (KabatZinn) (LEF, 163-167), and a strong emphasis on healthcare and sustainable consumption patterns. We easily recognise the LOHAS type in Nietzsche's "last man", the human being antagonistic to the "overman”, whom he portrays as follows: „Alas, the time of the most conspicable man is coming, he that is no longer able to despise himself. Behold, I show you the last man ... The earth has become small, and on it hops the last man, who makes everything small. His race is as ineradicable as the flea-beetle; the last man lives longest ... Becoming sick and harboring suspicion are sinful to them: one proceeds carefully ... One still works, for work is a form of entertainment. But one is careful lest the entertainment be too harrowing. One no longer becomes poor or rich: both require too much exertion... One has one's little pleasure for the day and one's little pleasure for the night: but one has a regard for health. "We have invented happiness "- say the last men, and they blink. "(Nietzsche 1954, 129-130) Nietzsche's Zarathustra, in his profound disdain for those last men, renounces all values attributed to their lifestyle. The overman, "the lightning out of the dark cloud of man" (Nietzsche 1954, 132), lives the dangerous life of a lion, not the life of a 'flea-beetle'.

Zarathustra doesn't know anything about the intersubjective elements of the U journey, like initiating core groups or creating circles (s. Fig. 1). He is the leader and prophet, his - nameless - disciples, albeit occasionally loved and missed by the master, have to listen and to obey. There is no such thing like substantial "co-creation" 8 at work in Zarathustra's teachings, an overlap can at best be assumed with regard to the U journey's co-presencing phases 9-12, which happen in a state of non-interactive introspection.

On the other hand, Scharmer repeatedly stresses the importance of interaction, group work and collective action in Theory U, elements which have no place in Nietzsche's world, but are perfectly compatible with the values of advanced democracies. Co-creative, participatory, inclusive democracy 4.0 could not be further from Nietzsche's intentions. The contradiction between Scharmer's attachment to Nietzsche and his appeal to collective transformational action is nowhere clarified, and far from resolved. Are the 4.0 change-makers the "first among equals" in their circles? Or are they little Zarathustras, prophets among their disciples, pre(or post) democratic agents of Nietzsche's "will to power"? Lacking any further elaboration by Scharmer, the prophetic language of Theory $U$ arguably gives the latter interpretation the edge.

\section{The Eastern Path of Wisdom in Theory U: Capra}

At the dawn of the "New Age" movements which emerged in the late 1960s, Buddhist and Taoist philosophy was met with huge enthusiasm by many Western intellectuals. They were almost magically attracted by its blend of religion and philosophy, detachment from a world stricken with power politics, violence and war, and its negation of the Cartesian-Newtonian subject/object dualism seen as a major force alienating man and nature. "Deep ecology" evolved as an approach of Western intellectuals who distanced themselves from the dominating Descartes-Newton paradigm in the natural sciences, and sought to align non-mechanistic and non-linear thinking in modern physics, biology and systems theory with the teachings of Buddha, Lao-Tzu and their disciples.

\footnotetext{
${ }^{8}$ However, Zarathustra demands of his disciples - in paternalistic generosity - to become "fellow creators". (Nietzsche 1954, 136)

9 The term „deep ecology“was introduced by Naess (1973)
} 
Inspired by the work of Gregory Bateson and Ken Wilber, Fritjof Capra was at the forefront of those scientists who embraced Buddhism and Taoism in order to address what they saw as a systemic crisis rooted in a profound cultural imbalance which they perceived in the prevalent value system of Western culture for at least 300 years. As a trained physicist, Capra specialised in particle physics and systems theory, his book "The Tao of Physics" (1975) became an international bestseller. In his later books "The Turning Point" (Capra 1982) and "The Hidden Connections" (2002) he applied the "deep ecology" approach to the social domain, blending systems theory and Buddhist thinking, particularly to the leadership in organisations and the transformation of global capitalism. Capra's popular endeavours into Eastern philosophy triggered a veritable pilgrimage of Western scientists to the Dalai Lama and other eminent Eastern thinkers; among them the Chilean biologist Francisco Varela.

In Theory $U$ the teachings of Capra are probably the most prominent source of references. Capra's elaborations on Bateson, Wilber, Husserl, Varela and Maturana - even Toynbee (Capra 1982, 7-12) - resurface all in Scharmer's books. Mutual personal acknowledgments in Theory $\mathrm{U}$ and "Hidden Connections" give further evidence of the powerful influence that Capra has had on the development of Scharmer's thinking.

Capra's diagnosis of Western culture highlights what he calls its fundamental "blind spots": the Cartesian-Newtonian "mechanistic" paradigm of science; the related distinction between mind and matter; linear thinking as opposed to non-linear system dynamics; a complete lack of insight that living organisms are "autopoietic", i.e. self-organising systems. ${ }^{10}$ Capra views social systems as "living systems", too, and finds it hard to understand (Capra 2004, 82) that Niklas Luhmann who developed a theory of social autopoiesis explicitly denies the property "living" to social systems (Luhmann 1986, 172-173). For him change, including social change, is - along the Buddhist path - a "natural tendency, innate in all things and situations" and "does not occur as a consequence of some force" (Capra 1982, 37). The roots of violence, war and power conflicts can be found in the undisciplined, alienated Western mind which is far from any harmonious balance in itself. Social conflict, viewed through the mirror of Eastern traditions, is transformed into an issue of human consciousness. "Buddhists regard the undisciplined mind as an unreliable instrument for observing different states of consciousness" (Capra 2004, 48). We find the same line of argument, embedded in the broader context of the Eastern philosophy's objective of the reintegration of matter and mind, ${ }^{11}$ outlined in Theory $U$ (TU, 53-54). However, the "natural tendency" or "natural flow of things" is not a terminology frequently adopted by Scharmer in Theory U. Just once, in his description of the "field structure of presencing", he uses the term "natural state" with a reference to Tibetan Buddhism to highlight that "mind and world are not separate" (TU, 168).

Having pursued Capra and Scharmer in their endeavour of the various blind spots in Western thought, we can now return the ball to their court and, vice versa, inquire about the blind spots of deep ecology: is the "natural flow of things" a tangible normative guideline, a source of value creation?

In a critical scrutiny of Capra's "deep ecology" thinking, S. Elkins recognises a twentieth century naturalism at work which transfers insights into the self-organised evolution of cells and larger living systems to the development of societies:

\footnotetext{
${ }^{10}$ The terms "autopoiesis" / "autopoietic systems theory" are borrowed from Varela et al. (1974) and Luhmann (1986); see (TU, 358-359)

${ }^{11}$ With an explicit reference to the Chinese Zen Master Nan
} 
"His (Capra's) assumption that alternative values, worldviews and principles of social organisation can be derived from insights into natural processes is highly problematic. A society's concept of nature is not an "objective" description taken from its natural environment. Rather, it is a social product; the result of cognitive, normative, and symbolic construction. In constructing nature, society can ultimately refer to nothing other than itself” (Elkins 1989-90, 63).

In the Western philosophical tradition that misleading transfer of rules, axioms, laws from the natural world to the moral world of human societies, with the purpose to build 'objective' normative guidelines, was introduced by D. Hume as the 'Is-Ought' problem and later elaborated by G.E. Moore in his examination of 'naturalistic fallacies'. Capra's arguments, derived from physics, biology and cybernetics, and transferred to human societies, never leave the circle of naturalistic fallacies. In 1976, one year after "The Tao of Physics", another prominent colleague of Capra, the biologist R. Dawkins released "The Selfish Gene" (Dawkins 1976) which pursues a similar line of naturalistic reasoning, but comes to the opposite conclusion: according to Dawkins the evolutionary selfishness of genes will usually give rise to selfishness in individual behaviour. The wisdom of Capra and the wisdom of Dawkins, both distilled from "nature" - as they construct and interprete natural phenomena -, lead to entirely different and ultimately incompatible norms and rules for society.

In his interpretation of systems theory Capra falls, as Elkins notes, into another epistemological trap when he disregards the effects of simplifying systemic relations: "Systems theory is no less "reductionist" than Newtonian mechanics. Its principle of reduction is merely different: the totality of ecological relations are selectively reduced to functional relations ... systems theory does not break with the logic of a utilitarian, exploitative relation to nature" (Elkins 1989-90, 65). Scharmer follows closely Capra's approach to systems theory and stresses, for the purpose of Theory U, that "all systems and knowledge are situated in context" (TU, 106). The universal situatedness or embeddedness of knowledge and cognition in real life is in Scharmer's view the source of the phenomenon of 'deep emergence', of the emergence of self-transcending knowledge after a successful journey along the U. That cognitive perspective leads us to the work of Franciso Varela and its impact on Theory U.

\section{The Path of Letting-Go: Varela}

Francisco Varela, mutually acknowledged by both Capra and Scharmer as an important contributor to their work, was a biologist, philosopher, and neuroscientist who, together with his teacher Humberto Maturana, is best known for introducing the concept of "autopoiesis" (Varela et al. 1974) to biology and further to cognitive science. Based on their joint research on autopoietic dynamics in organic systems, Varela conceived a new field of cognitive research, "neurophenomenology". Scharmer's acknowledgment of Francisco Varela: “...to whom I owe the three folds of the core process of becoming aware: suspension, redirection and letting go (which mark the left-hand side of the U)" (TU, xxii) gives a precise idea of the profound impact that Varela had on the grounding of Theory U.

Varela, a devoted Buddhist practitioner since 1974, served as a senior advisor to the 14th Dalai Lama and participated in the "Mind and Life" dialogues which were set up to explore concurrent methodological approaches and common topics of Western science and Buddhist wisdom traditions. In his late book "Ethical Know-How - Action, Wisdom and Cognitions" (Varela 1999) Varela blended his research on neurobiology and cognitive science with Eastern 
thinking to achieve a new understanding of ethical behaviour. In a clear renunciation of the Kantian tradition of deducting moral judgments from rational and universal ethical principles, Varela turns his attention to the East: "Ethics is closer to wisdom than to reason ... why should one conflate ethical behavior with judgment?" (Varela 1999, 3-4) Varela finds in the teachings of Taoism and Buddhism more convincing approaches to cultivate ethical behaviour "pragmatically and progressively", captured in a nutshell by the Taoist notion of "wu-wei", the "not-doing" (Varela 1999, 32): "wu-wei points to a journey of 'experience' and 'learning', not to a mere intellectual puzzle that one solves. It points to the process of acquiring a disposition where immediacy precedes deliberation, where nondual action precedes the radical distinction between subject and object" (Varela 1999, 33). In other words, ethical expertise is achieved by uncovering compassion which arises directly and spontaneously out of real life experience. The precondition of such a 'wu-wei' ethical training is the "letting-go of egocentered habits" (Varela 1999, 73) and norms acquired by rational deliberation.

Here we find ourselves in the opening process of the journey of the $U$ along the downward trajectory, outlined by Scharmer in an explicit reference to Varela: "Varela was talking about the deep folds in the structure of our attention that begin to unfold as we progress through the cycle of becoming aware: suspending habitual judgment; redirecting attention from perceived objects to the process of collectively co-creating them; and finally, changing the quality of our attention by letting go of old identities and intentions and allowing something new to come in some emerging future identity and purpose" (TU, 36; emphasis in original). "Letting-go" (and its counterpart "letting-come" along the later upward journey of the U) is a key term in Scharmer's work and used 78 times in Theory U. ${ }^{12}$ Varela and Scharmer find in the path of letting-go a door to the "unproblematic warmth toward the world" (Varela 1999, 70) which they miss in the Western modern ethical thinking and its "nihilistic flavor" (Varela 1999, 24).

In his critical but highly respectful review of "The Tree of Knowledge" (Maturana and Varela 1987), M. Berman emphasizes the "obvious "Eastern" - specifically Buddhist flavor" of Maturana's and Varela's thinking (Berman 1989, 281). He outlines the blind spots linked to that 'flavor' in a fundamental caveat about its "curious apolitical atmosphere": "Cognitively speaking, the substitution of Buddhism for politics is a serious error, leaving, as it does, too many crucial questions unanswered." (Berman 1989, 278) Indeed, war and violence and competition are interpreted as 'aberrations' of our fundamentally compassionate biological (not cultural) constitution where "authentic care resides at the very ground of Being" (Varela 1999, 73). Grounded in an assumed 'biology of cooperation', Varela's Ethical Know-How and Scharmer's Theory U fall into a too benign naturalistic fallacy which prevents a full understanding of the origins of human conflicts, as those supposed 'aberrations' have no proper source and systemic place in their view of the world. That blind spot is unwillingly illuminated in Varela's disturbing 'analysis' of the Chilean Civil War (Chile is his home country) which he saw as a result of a "wrong epistemology" (Varela 1979, 19). In a similar "play down" mode, Scharmer interpretes the essential problem behind the "Bush-Cheney-Rumsfeld vision leading up to the Iraq War" as a "lack of listening" (LEF, 113). Referring to a small successful protest of Jewish women in Berlin 1943 against the arrest of their husbands by Gestapo agents (the protest led to their release and saved them from deportation to Auschwitz), he challenges the view that "it's not good enough to keep focusing on Gandhian types of nonviolent strategies of conflict transformation" (TU, 444). Alas, history's lesson was that those nonviolent strategies weren't good enough to prevent the Holocaust. Such striking apolitical naivete in the face of

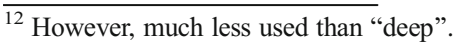


brutal violence and lethal military power reveals the common conceptual weakness of Capra, Varela and Scharmer: the "Eastern flavor" is too sweet for mankind, it does not stand up to a serious reality check. In his review Berman concludes: "Love' may indeed, as they claim, bring forth the world, but the human race has created many worlds, and sad to say, most of the recent ... ones are not very lovely. The Chilean/Buddhist model of reality is only true in an abstract or idealized universe, or in one that is no longer with us" (Berman 1989, 281).

\section{Intentionality, Intersubjectivity, Rationality: Husserl and Theory U}

Among European thinkers the work of the Austrian-German philosopher Edmund Husserl became a cornerstone of Varela's endeavors in the field of phenomenology.

Scharmer draws a direct line from Varela back to Husserl, assuming that Varela's work represents a modernized approach and extension ("neurophenomenology") of Husserl's orginal concept of phenomenology. Thus, he claims that Theory U pursues "... the same way that Husserl and Varela advocated in their work on the phenomenological method" (TU, 31), fully deploying its potential to "immerse in the real world", achieve an "action oriented science", and ultimately evoke the "knowing of the heart": "Love is the deepest knowledge of things"13 (TU, 109). In other words, Scharmer invites Husserl to a ride along the U curve for a "boundary shift" that would redirect his philosophical enquiry to the epistemological and ontological "source" level.

Two terms of phenomenological research play a key role here, intentionality and intersubjectivity. The concept of intentionality describes a mental act of the consciousness towards an object which makes the object in the mind's intention a part of the mental act itself. ${ }^{14}$ Intersubjectivity, in Husserl's interpretation as "transcendental intersubjectivity", is the relationship between the consciousnesses of the two subjects "I / Ego" and "Other" that can be analysed only within this relationship, starting from the "I".

On the journey down the left side of the U we leave, step by step, the Cartesian world: the reduction of real life complexities, the pending of judgments, the abandoning of the entirely ego-oriented search for truth (in Husserl's words, "egology"). That process transforms profoundly our intentionality towards the "Other". Having left the Cartesian world behind and passing the bottom of the $U$ in the phase of "co-presencing", the disciples enter the state of "intentional silence". ${ }^{15}$ Moving up the right side of the $U$ they finally reach the phase of "coevolving", or "intentional grounding". At that stage the journey opens the window to "cocreativeness", a self-transcending knowledge, and a higher level of intersubjectivity.

Would Varela have endorsed that juxtaposition of Scharmer's co-creativeness and Husserl's concept of intersubjectivity? I doubt it. In Varela's examination of Husserl's research on time consciousness (Varela et al. 1991, 16-17), "the Husserlian attempt to have access to the structure of the experience itself thanks to the "epoché"16 of the empirical world cannot succeed, according to Varela, insofar as Husserl, prisoner of a Cartesian philosophy, fails to take the step that follows the one he had the merit of

\footnotetext{
${ }^{13}$ Scharmer adapts that phrase from the Japanese philosopher Kitaro Nishida.

${ }^{14}$ Husserl follows the definition of intentionality of his teacher Franz Brentano: "Every mental phenomenon includes something as object within itself, although they do not all do so in the same way. In presentation something is presented, in judgement something is affirmed or denied, in love loved, in hate hated, in desire desired and so on. This intentional in-existence is characteristic exclusively of mental phenomena. No physical phenomenon exhibits anything like it“(Brentano 2015 / (1874), 92-93)

15 s. Figure 1

${ }^{16}$ Husserl's term for the suspension of judgment and primordial phenomenological reduction/introspection.
} 
exploring. This block comes from the fact that he began with the Cartesian principle of the mind as subjective consciousness" (Dosse 1999, 176). For Varela, Husserl's thinking lacks completely the pragmatic, "embodied" dimension of intentionality, and cannot overcome the traditional distinction between science and experience, mind and body, contrary to Varela's concept of a "naturalized intentionality".

Indeed, Husserl never abandons the primary status of the rational subject.

There is no "same way" of Husserl and Varela apart from Varela's use of Husserlian terminology. The fundamental divide between them is evident in Husserl's careful distance to any kind of "naturalization" of (embodied) consciousness and intentionality (in the sense of Varela's concept of "enaction"), or of any other nonrational approach to phenomenological research.

Contrary to Varela and Scharmer, Husserl's thinking is firmly rooted in the rationalist tradition of Cartesian phenomenology: the mind is entirely subjective consciousness and performs mental acts of abstract philosophical introspection (epoché) to achieve an understanding of the essential and pure structures of consciousness. No evidence can be found for Scharmer's claim that the later works of Husserl, especially his concepts of a "transcendental self" and a "living presence" are precursors of key elements of Theory U: co-creation and social presencing (TU, 99; 108). Those late writings, the "Fifth Cartesian Meditation" and the "Crisis of the European Sciences", do indeed tackle the issue of intersubjectivity. However, as H.B. Schmidt has elaborated in his work on Husserl's transcendental subjectivity, they never weigh their anchor, the 'ego power' sphere of the rational, lonely subject. ${ }^{17}$ That monologistic stance of the rational subject seeking truth solely in itself has engendered the criticism of sociologists and philosophers like Michael Theunissen, Niklas Luhmann and Jürgen Habermas: in Husserls theoretical framework the reflexive-rational subject "I" cannot find a way to the "Other" without sacrificing the introspective methodology of phenomenology itself (Schmid 2000, 12).

Husserl is acutely aware of that dilemma in his last works, he finds no solution in philosophy, but in religion, in the prayer as a 'transcendental communitarisation' (Schmid 2000, 171). The common prayer in the religious community gives access, 'inner direction' by spiritual interaction with other human beings. Yet, as Schmid has shown, Husserl's turn towards religion plays a marginal role in his late work, and takes place in a sphere beyond his philosophical investigations; a move similar to the Christian eschatological consolations of the pessimistic Toynbee beyond his work as a historian. Scharmer discovers a weak link in Husserl's brief references to religion and assumes that Theory $U$ and transcendental phenomenology connect in their search for non-rational "deep" sources of the self. Hence his remark: "Yet Husserl and Heidegger both leave the impression that perhaps the most important aspect of their work is yet to be done" (TU, 109). But no explanation is given what that mysterious 'most important aspect' may be. Schmid points out that nothing in Husserl's transcendental phenomenology corresponds substantially with intersubjective inspirations drawn from prayer or religious practice (Schmid 2000, 171-172). We have to search elsewhere to learn more about that 'most important aspect' assumed by Scharmer; and find its source in Anthroposophy.

\footnotetext{
${ }^{17}$ Husserl borrows a phrase from St. Augustine which concludes his 'Cartesian Meditations' to illustrate the categorically introspective character of the phenomenological reduction: "Noli foras ire, in te redi, in interiore homine habitat veritas." (Don't go astray, return to yourself, inside of you lives the truth) (Husserl 1973, 183)
} 


\section{Anthroposophy and Theory U}

In his introductory remarks on Theory U, Scharmer highlights the quintessential role of Rudolf Steiner's work for his thinking: "Among the philosophical sources, perhaps most influential was the work of the educator and social innovator Rudolf Steiner, whose synthesis of science, philosophy, consciousness and social innovation continues to inspire my work and whose methodological grounding in Goethe's phenomenological view of science has left significant imprints on Theory U" (TU, 30-31). ${ }^{18}$

Steiner is the founder of Anthroposophy, one of the most successful spiritual movements in Europe. It has generated the Waldorf school pedagogy and made Waldorf schools one of the leading initiatives of private education in Europe, covering today a wide range of institutions from kindergardens to universities. Anthroposophic medicine has developed alternative therapies based on the healing forces of herbs, its "bio-dynamic" practice of agriculture has become one of the most influential promoters of organic agriculture in Europe, and gained recognition far beyond anthroposophic circles.

Scharmer grew up in a family of farmers practising "bio-dynamic" agriculture, attended a Waldorf (Steiner) school, and studied at the University of Witten-Herdecke, founded by members of the anthroposophical movement (Gerhard Kienle, Konrad Schily). A colleague with a similar background explained to me: "If you are familiar with anthroposophic thinking, you find it almost everywhere 'between the lines' in Theory U". ${ }^{19}$ Indeed, Theory U is awash with references to Steiner's thoughts. The study of Steiner led Scharmer to the work of Friedrich Glasl, an internationally recognised researcher on conflict resolution, whose " $U$ procedure" Scharmer used and confirmed as the prototype of the U journey (TU, 31).

Rudolf Steiner repeatedly insisted in his writings that he is doing science, interchangeably adding the adjectives "occult", "divine" or, most commonly, "spiritual" (Steiner 1947, 1-34). "The spiritual scientist's way of looking at things is wholly in keeping with the methods of natural science. However, it must certainly be clear that since spiritual science covers an entirely different field from the external sense perceptible field covered by natural science, researching the spiritual realm requires a fundamental modification of the natural scientific approach. The methods of the spiritual science are in keeping with those of natural science in the sense that any unprejudiced person trained in natural science can accept the premises of spiritual science." (Steiner 1985, 1).

Similarly, Scharmer ascertains that Theory $U$ is bound "to extend the philosophical and scientific investigation" (TU, 109). However, he claims that "to view science from the viewpoint of the artist means to apply scientific investigation not only to the object in front of us but also to the creative process and the scientist/artist who is performing that activity". (TU, 108) A critical scrutiny has to clarify whether, according to Scharmer's claim, we find in Theory $U$ a convincing synthesis of the three Aristotelian types of knowledge he refers to: science/episteme; art/techne; and practical wisdom/phronesis (TU, 108). Or whether that "crossover" ultimately ends in confusion. So far we have investigated his comments on Nietzsche, Capra, Varela and Husserl and didn't find any coherent philosophical grounding of such a crossover.

In the case of Steiner, the epistemic faultlines of his spiritual teachings don't lead us to a scientific or 'non-spiritual' synthesis, either. The Swedish philosopher Sven-Ove Hansson has

\footnotetext{
${ }^{18}$ With a special reference to Steiner's book „Philosophy of Freedom“

${ }^{19}$ In a discussion with Florian Boukal, M.A.
} 
reviewed and tested the anthroposophical road to knowledge against the two basic scientific criteria of intersubjectivity and testability of predictions. According to his enquiry, Anthroposophy clearly fails to meet those basic criteria of scientific rationality. Hansson concludes: "The problem is that there is virtually nothing left that anthroposophy can have in common with science. ... What remains then, is essentially the functions that are traditionally claimed for religion: consolation, a sense of meaning and purpose, hope for after-life, foundations for morality." (Hansson 1991, 45; 46).

That tension between science/rationality and religion/spirituality reverberates in the relationship of Husserl and Steiner. Both attended lectures of Franz Brentano, an eminent psychologist in Vienna in the late nineteenth century. Husserl, the devoted rationalist, distanced himself sharply from "Steinerianism", as he called it, which he saw as a pseudoreligious movement, a symptom of the "crisis of European man": "Mystical movements, like Steinerianism, are spreading incredibly and purport to be the true "humanities", elevating man above the empirical. Restlessly tortured for years, the souls are full of fervent longing for redemption, and they fall prey to obscure reveries or seek salvation in old and new religion." (Husserl 1994a, 114). ${ }^{20}$

On his part, Steiner referred to Husserl as a philosopher "hard to capture": “...nothing special will come of it. In his confusion across all controversies nothing tangible is achieved" (Steiner 2005, 501-502). ${ }^{21}$ The mutual disdain is evident and understandable, as Steiner and Husserl, the prophet and the philosopher, don't even share basic values how to do scientific research and how to apply philosophical insights to human development and societal transformation.

\section{Conclusion, and a Practitioner's Comment}

Apart from the rich narrative resources gathered in countless meetings and interviews in which Scharmer has embedded the journey of the $U$, his great merit is the serious attempt to provide an ambitiously comprehensive grounding of his theory in philosophy and historical science. Our critical examination has proven that this attempt is evidently falling short of understanding real world complexity and matching widely acknowledged academic standards. Its flawed or even contradictory references to philosophical sources remain elusive and don't lead to a convincing epistemic "grounding" of Theory U.

Scharmer /Kaufer are fully aware that there might be a serious problem for the more sceptical minds among us when they recount the inspiration ("You ... are the cradle of my rebirth") of a member in one of their former peer groups: "This may sound airy-fairy or sentimental to some, but it is in fact an accurate description of a subtle experience that all of us - and many others in their circles - have experienced." (LEF, 243-244).

Stripped down to its essence, Theory $U$ does indeed sound airy-fairy, comes dangerously close to the - in Husserl's words - 'obscure reveries' of Steiner, and ultimately brings forth more 'nonsensing' than 'presencing'.

\footnotetext{
${ }^{20}$ translation by the author; letter to T.G. Masaryk 2.3.1922; a similar statement in Husserl's letter to W.P. Bell 18.9.1921 in (Husserl 1994b, 24-25).

${ }^{21}$ translation by the author.
} 
However, Scharmer is the first researcher on organisational leadership who has broadly embraced non conventional schools of thought, and thus gone far beyond the predominant personality or relationship based approaches and behavioural mindsets which still govern the mainstream literature on leadership theories. ${ }^{22}$

Liberated of its incoherencies, sociopolitical naiveté and messianic jargon, Theory U has certainly the potential to be transformed into a rather useful approach to new ways of leadership and the challenges of change management. As a next step, a healthy dose of humility and 'Western' rationality in the tradition of Kant and Husserl would probably suffice for a valuable upgrade to Theory $U$ 2.0.

Over the last years the academic teaching practice of Theory $U$ has been significantly upscaled by the launch of the "U.lab" which offers massive open online courses (MOOCs) on Theory $U$ and reaches out to a much wider audience than its readership. Working with Theory $\mathrm{U}$ in seminars for organizational leaders and students alike should follow a "letting go" approach which detaches the qualities of Theory U, particularly its emotional intelligence, wide intellectual range and transdisciplinarity, from its incoherent doctrines of historic and social evolution and its philosophical inconsistencies. It remains to be seen whether Scharmer and his followers take on the challenge.

Compliance with Ethical Standards The corresponding author states that his research did not involve collecting primary data. The article has been written in full compliance with the COPE guidelines.

Conflict of Interest The corresponding author states that there is no conflict of interest.

Open Access This article is distributed under the terms of the Creative Commons Attribution 4.0 International License (http://creativecommons.org/licenses/by/4.0/), which permits unrestricted use, distribution, and reproduction in any medium, provided you give appropriate credit to the original author(s) and the source, provide a link to the Creative Commons license, and indicate if changes were made.

\section{References}

Amanchukwu, R.N., G.J. Stanley, and N.P. Ololube. 2015. A review of leadership theories, principles and styles and their relevance to educational management. Management 5 (1): 6-14. https://doi.org/10.5923/j. mm.20150501.02.

Aron, R. 1961. L'Histoire et ses interprétations : Autour d'Arnold Toynbee. Paris - La Haye: Edition Mouton \& Co.

Avolio, B.J., F.O. Walumbwa, and T.J. Weber. 2009. Leadership: Current theories, research, and future directions. Annual Review of Psychology 60: 421-449.

Berman, M. 1989. The roots of reality: Maturana and Varela's the tree of knowledge. Journal of Humanistic Psychology 29 (2): 277-284.

Bershidsky, L. 2013. Why are Google Employees so disloyal? Bloomberg News. https://www.bloomberg. com/view/articles/2013-07-29/why-are-google-employees-so-disloyal Retrieved 20.11.2016.

Brentano, F. 2015. Psychology from an Empirical Standpoint (ed. crane, T., and Wolff, J.) New York: Routledge (originally released 1874).

Capra, F. 1982. The turning point: Science, society and the rising culture. London: Wildwood House.

Capra, F. 2004. The Hidden Connections: A Science for Sustainable Living. New York: Anchor Books. (First edition 2002).

Clark, L. 2017. Loopholes and luxuries: how Apple, Facebook and Google stay ahead of the tax man, $4^{\text {th }}$ May. WIRED. http://www.wired.co.uk/article/facebook-apple-tax-loopholes-deals Retrieved 14.8.2017.

Coulborn, R. 1956. Fact and fiction in Toynbee's study of history. Ethics 66 (4): 235-249.

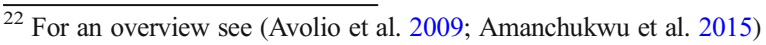


Dawkins, R. 1976. The selfish Gene. Oxford: Oxford University Press.

Dosse, F. 1999. The Empire of Meaning-The Humanization of the Social Sciences. Minneapolis. London: University of Minnesota Press.

Elkins, S. 1989. 90. The politics of mystical ecology. In Telos, vol. 82, 52-70.

EU Leonardo Awards. 2016. http://www.leonardo-award.eu/content/e19/e2619/e2565/index_eng.html Retrieved 20.8.2017.

Foucault, M. 1977. Nietzsche, genealogy, history. In Language, counter-memory, practice: Selected essays and interviews, ed. D.F. Bouchard, 139-164. Ithaca: Cornell University Press.

Geyl, P. 1955. Toynbee the prophet. Journal of the History of Ideas 16 (2): 260-274.

Graeber, D. 2011. Debt: The first 5000 years. New York: Melville House.

Gunnlaugson, O., Ch. Baron, and M. Cayer. 2013. Perspectives on theory U: Insights from the field. Hershey: IGI Global.

Hale, F. 2005. H.R. Trevor-Roper vs. Arnold Toynbee: A post-Christian Religion and a new Messiah in an age of reconciliation? Verbum et Ecclesia 26 (1): 93-113.

Hansson, S.O. 1991. Is anthroposophy science? Conceptus XXV, nr. 64: 37-49.

Husserl, E. 1973. Cartesianische Meditationen und Pariser Vorträge (Husserliana Bd.I). Den Haag: Martinus Nijhoff.

Husserl, E. 1994a. Briefwechsel Bd. I. Dordrecht: Kluwer Academic Publishers.

Husserl, E. 1994b. Briefwechsel Bd. III. Dordrecht: Kluwer Academic Publishers.

Losurdo, D. 2009. Nietzsche, der aristokratische Rebell. Hamburg: Argument Verlag. (orig: Losurdo, D. 2002. Nietzsche, il ribelle aristocratico. Biografia intellettuale e bilancio critico. Torino: Bollati Boringhieri)

Luhmann, N. 1986. The autopoiesis of social systems. In Sociocybernetic Paradoxes, ed. F. Geyer and J. van der Zouwen, 172-192. London: SAGE Publishing.

Lukács, G. 1980. Nietzsche as founder of irrationalism in the imperialist period. In: The Destruction of Reason (transl. by Peter Palmer). London: The Merlin Press, 309-399.

Maturana, H.R., and F.J. Varela. 1987. The tree of knowledge. Boston: Shambhala Publications.

MIT Sloan School of Management, Faculty Directory. 2017. http://mitsloan.mit.edu/faculty-andresearch/faculty-directory/detail/?id=41401 Retrieved 15.8.2017.

Montagu, A., ed. 1956. Toynbee and history: Critical essays and reviews. Boston: Porter Sargent.

Naess, A. 1973. The Shallow and the Deep, Long-Range Ecology Movement. A Summary. Inquiry 16, no. 1 [Spring], 95-100.

Nietzsche, F. 1954. Thus spoke Zarathustra. In: The Portable Nietzsche (edited and translated by Walter Kaufmann), 103-439. New York: The Viking Press/Penguin Group.

Pfeffer, J. 2015. 3 lessons from the Amazon takedown. Fortune. http://fortune.com/2015/08/18/amazon-newyork-times. Retrieved 3.10.2017.

Prahalad, K.C., and V. Ramaswamy. 2004. The future of competition: Co-creating unique value with customers. Boston: Harvard Business School Press.

Scharmer, C.O. 2007 ( $1^{\text {st}}$ ? edition). Theory U. San Francisco: Berrett-Koehler Publishers.

Scharmer, C.O. 2016 ( $2^{\text {nd }}$ ? edition). Theory U. San Francisco: Berrett-Koehler Publishers.

Scharmer, C.O., and K. Kaufer. 2013. Leading from the emerging future. San Francisco: Berrett-Koehler Publishers.

Schmid, H.B. 2000. Subjekt, System, Diskurs-Edmund Husserls Begriff transzendentaler Subjektivität in sozialtheoretischen Bezügen. Dordrecht/Boston/London: Kluwer Academic Publishers.

Schwab, K.. 2015. The Fourth Industrial Revolution: what it means, how to respond. Foreign Affairs. https://www.foreignaffairs.com/articles/2015-12-12/fourth-industrial-revolution. Retrieved 10.06.2017.

Steiner, R. 1947. Knowledge of the higher worlds and its attainment. Hudson: Anthroposophic Press.

Steiner, R. 1985. Anthroposophy and Christianity. Spring Valley: Anthroposophic Press.

Steiner, R. 2005. Fachwissenschaften und Anthroposophie (GA Band 073a). Dornach (CH): Rudolf Steiner Verlag.

Sun, E. 2012. Alibaba Fraud Report. Amazon Digital Services LLC. https://www.amazon.com/Alibaba-FraudReport-ebook/dp/B00A4EM7X0/ref=sr_1_4?ie=UTF8\&qid=1364455120\&sr=8-4\&keywords=alibaba .

Toynbee, A. 1934-1961. A Study of History, 12 Volumes. Oxford: Oxford University Press.

Toynbee, A. 1947. A Study of History. Abridgement of Vol. I-VI by D.C. Somervell. Oxford: Oxford University Press.

US Department of Justice. 2014. Justice Department Announces Criminal Charge Against Toyota Motor Corporation and Deferred Prosecution Agreement with \$1.2 Billion Financial Penalty, March 19. https://www.justice.gov/opa/pr/justice-department-announces-criminal-charge-againsttoyota-motor-corporation-and-deferred Retrieved 20.11.2016.

Varela, F.J. 1979. Reflections on the Chilean Civil War. Lindisfarne Letter 8 (winter): 13-19.

Varela, F.J. 1999. Ethical know-how: Action, wisdom, and cognition. Stanford: Stanford University Press.

Varela, F.J., H.R. Maturana, and R. Uribe. 1974. Autopoiesis: The organization of living systems, its characterization and a model. Biosystems 5 (4): 187-196. 
Varela, F.J., E. Thompson, and E. Rosch. 1991. The embodied mind: Cognitive science and human experience. Boston: MIT Press.

Vuori, T.O., and Q.N. Huy. 2015. Distributed attention and shared emotions in the innovation process: How Nokia lost the smartphone battle. Administrative Science Quarterly XX: 1-43.

Peter W. Heller is a former Deputy Mayor of the City of Freiburg im Breisgrau, Germany. He is an environmental scientist and venture philanthropist. He studied economics and philosophy.

In 2001 he co-founded the „Basel Agency for Sustainable Energy (BASE)“, a „Collaborating Center“ of UNEP, and is a member of the foundation board. Since 2011 Heller serves on the Board of Trustees of the European Environment Foundation, Basel, which holds an annual international convention of Environmental Laureates. In 2015 the General Assembly of the HUMBOLDT-VIADRINA Governance Platform gGmbH elected him as Chairman. 